\title{
SOLID PSEUDOPAPILLARY TUMOUR OF THE PANCREAS- A SINGLE INSTITUTION STUDY OF THREE CASES WITH A BRIEF REVIEW OF LITERATURE
}

\author{
Zeenat Sarmadi Imam¹, Reecha Singh², Bipin Kumar³, Kalpana Chandra4 ${ }^{4}$ Mona Lisa ${ }^{5}$ \\ ${ }^{1}$ Senior Resident, Department of Pathology, Indira Gandhi Institute of Medical Sciences, Patna. \\ ${ }^{2}$ Associate Professor, Department of Pathology, Indira Gandhi Institute of Medical Sciences, Patna. \\ ${ }^{3}$ Professor and HOD, Department of Pathology, Indira Gandhi Institute of Medical Sciences, Patna. \\ ${ }^{4}$ Assistant Professor, Department of Pathology, Indira Gandhi Institute of Medical Sciences, Patna. \\ ${ }^{5}$ Senior Resident, Department of Pathology, Indira Gandhi Institute of Medical Sciences, Patna.
}

\section{BACKGROUND}

ABSTRACT

Solid Pseudopapillary Tumour (SPT) of the pancreas is a distinctive tumour of low malignant potential with a predilection for females in the second and third decades of life. We report here 3 cases because of its rarity and we attempt to briefly review the literature of this distinctive lesion.

\section{MATERIALS AND METHODS}

A total of 3 cases were diagnosed and treated in our institute over a 2 -year period. A retrospective study of these cases was performed with respect to age group most frequently affected, sex ratio, common presenting symptoms and signs, investigative protocols, pathological features, treatment offered, outcome and prognosis. All the three patients were females with the age of presentation of 20 yrs., 14 yrs. and 15 yrs. respectively. The commonest presenting symptom was abdominal pain. The patients underwent distal pancreatectomy, Whipple's resection and pancreaticoduodenectomy with appendicectomy respectively. Histological diagnosis was made by performing haematoxylin-eosin staining and confirmed by immunohistochemistry.

\section{RESULTS}

All the patients were females in the age group of 13 - 25 years. Pre-operative imaging is not diagnostic. Pathological examination is the mainstay in the diagnosis. No metastasis or recurrence was detected during followup.

\section{CONCLUSION}

Solid pseudopapillary tumour of the pancreas is a rare entity, therefore proper diagnosis, evaluation and formulation of treatment protocols is difficult. A high index of clinical suspicion is necessary to suspect and diagnose it. Surgical excision offers the best chance for cure and should always be attempted irrespective of the magnitude of the resection involved. The results of immunohistochemical and ultrastructural studies indicate that it must be regarded as a tumour of uncertain histogenesis and undetermined differentiation.

\section{KEYWORDS}

Solid, Pseudopapillary, Neoplasm, Pancreas.

HOW TO CITE THIS ARTICLE: Imam ZS, Singh R, Kumar B, et al. Solid pseudopapillary tumour of the pancreas- a single institution study of three cases with a brief review of literature. J. Evolution Med. Dent. Sci. 2018;7(04):540-543, DOI: $10.14260 /$ jemds/2018/120

\section{BACKGROUND}

Solid Pseudopapillary Tumour (SPT) is a rare primary exocrine pancreatic neoplasm occurring in about $1 \%$ of pancreatic tumours.[1] Most cases are found in young women in second to fourth decade of life ${ }^{[2,3]}$ with non-specific symptoms including abdominal discomfort, subtle abdominal pain or abdominal mass. It is a well encapsulated, relatively benign tumour having a favourable prognosis. The presence of extrapancreatic invasion, distant metastasis, pancreatic parenchymal invasion, perineural or vascular invasion have been considered to be features of malignancy.

'Financial or Other Competing Interest': None.

Submission 07-12-2017, Peer Review 06-01-2018,

Acceptance 13-01-2018, Published 22-01-2018.

Corresponding Author:

Dr. Zeenat Sarmadi Imam,

C/O Mr. Zafar Imam,

House No. 1, Main Road,

Barinagar, Telco, Jamshedpur-831004,

Jharkhand.

E-mail:dr.zimam@gmail.com

DOI: $10.14260 /$ jemds $/ 2018 / 120$

\section{(c) $($ ) $\$$}

SPT of the pancreas most commonly arise in the pancreas, while retroperitoneum is the second site of involvement.[4] We report here three cases because it is important to differentiate this tumour from other pancreatic neoplasms, as this type is amenable to cure with surgical resection, even in cases with capsular invasion, unlike malignant tumours of pancreas.

\section{MATERIALS AND METHODS}

Clinical records with follow-up information were studied for 3 cases of SPT of the pancreas, diagnosed and treated in our hospital between 2015 and 2017. The clinico-pathological, radiological, operative and survival data were obtained. A CT scan of the abdomen was performed in all the cases and the findings revealed a mass in the pancreas. Histological diagnosis was made by performing haematoxylin-eosin staining and confirmed by immunohistochemistry using a panel of markers. All the patients were followed up every 6 months. Routine blood tests, biochemical analysis, chest $\mathrm{x}$ ray, ultrasound or a CT scan abdomen along with CA 19-9 were performed in the follow-up period. 


\section{RESULTS}

All the patients were females in the age group of 14 to 20 years (median 15 years). Two patients presented with pain abdomen and abdominal lump gradually increasing in size (67\%). One presented with a painless abdominal mass (33\%) in the epigastrium. The tumour was located in the head of the pancreas in two cases (67\%) and in the tail in one case (33\%). The tumour size ranged from 6 to $10 \mathrm{~cm}$ (average 7.3 $\mathrm{cm})$.

The patients underwent distal pancreatectomy, Whipple's resection and pancreaticoduodenectomy with appendicectomy respectively. The postoperative hospital stay was uneventful. All the 3 patients are disease free in the follow-up period. Details of the cases are summarised in Table 1 and Table 2.

\begin{tabular}{|c|c|c|c|c|c|c|}
\hline ஸे & 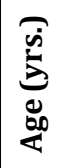 & 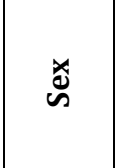 & : & 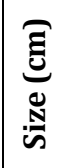 & 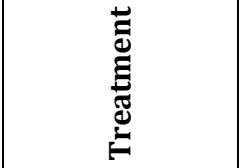 & \begin{tabular}{l}
\multirow{7}{7}{} \\
3 \\
0 \\
0 \\
0 \\
0
\end{tabular} \\
\hline 1 & 20 & Female & Tail & 6 & $\begin{array}{c}\text { Distal } \\
\text { pancreatectomy }\end{array}$ & $\begin{array}{l}24 \text { months - no } \\
\text { evidence of } \\
\text { disease }\end{array}$ \\
\hline 2 & 14 & Female & Head & 10 & $\begin{array}{l}\text { Whipple's } \\
\text { procedure }\end{array}$ & $\begin{array}{c}10 \text { months - no } \\
\text { evidence of } \\
\text { disease }\end{array}$ \\
\hline 3 & 15 & Female & Head & 6 & $\begin{array}{c}\text { Pancreatectomy } \\
\text { with } \\
\text { appendicectomy }\end{array}$ & $\begin{array}{c}16 \text { months - no } \\
\text { evidence of } \\
\text { disease }\end{array}$ \\
\hline
\end{tabular}

\begin{tabular}{|c|c|c|c|}
\hline Marker & Case 1 & Case 2 & Case3 \\
\hline $\begin{array}{c}\text { Alpha-1 } \\
\text { antitrypsin }\end{array}$ & +ve & +ve & Not included \\
\hline Beta catenin & Not included & +ve & +ve \\
\hline CD 56 & Strongly +ve & Strongly +ve & Strongly +ve \\
\hline CD 10 & Weakly +ve & Weakly +ve & Strongly +ve \\
\hline Vimentin & +ve & +ve & Not included \\
\hline Synaptophysin & -ve & -ve & -ve \\
\hline Chromogranin & -ve & -ve & -ve \\
\hline $\begin{array}{c}\text { Progesterone } \\
\text { Receptor }\end{array}$ & Not included & Not included & Strongly +ve \\
\hline Cyclin D1 & Not included & Not included & Strongly +ve \\
\hline CK 8/ CK 18 & -ve & -ve & -ve \\
\hline \multicolumn{4}{|r|}{ Table 2. Immunohistochemical Study } \\
\hline
\end{tabular}

\section{DISCUSSION}

SPT of the pancreas was first described by Frantz in 1959.[5] It predominantly occurs in young females, but has been reported in males and children. Zhou et al reported that SPT was probably the most common pancreatic tumour in the Asian paediatric population.[6] In our series, all patients were females with a median age of 15 years [Table 1]. The most common clinical presentation is a palpable abdominal mass and abdominal pain.[7] Depending on the location of the tumour in the pancreas (head, body or tail), the differential diagnosis includes pancreatic endocrine tumours, mucinous cystadenoma, acinar cell carcinoma and pseudocyst.

Preoperative imaging is not diagnostic. However, ultrasonography, CT scan, MRI and endosonography are the commonly used radiological modalities. CT scan is more sensitive and specific and has shown greater accuracy in diagnosing SPT. In our series, CT scan was performed in all the 3 cases.

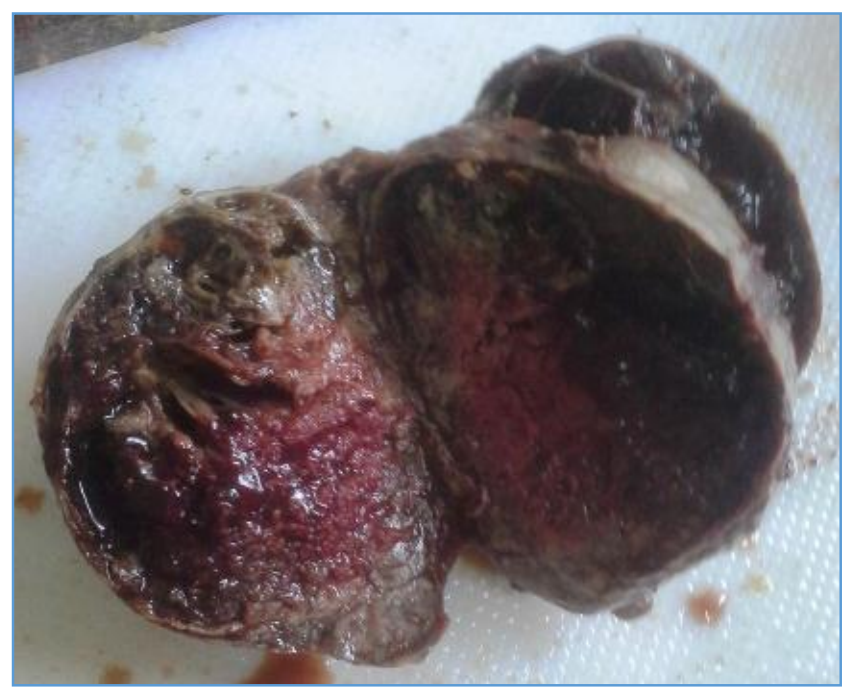

Figure 1. Encapsulated Solid/Cystic Mass showing Haemorrhagic and Necrotic Areas

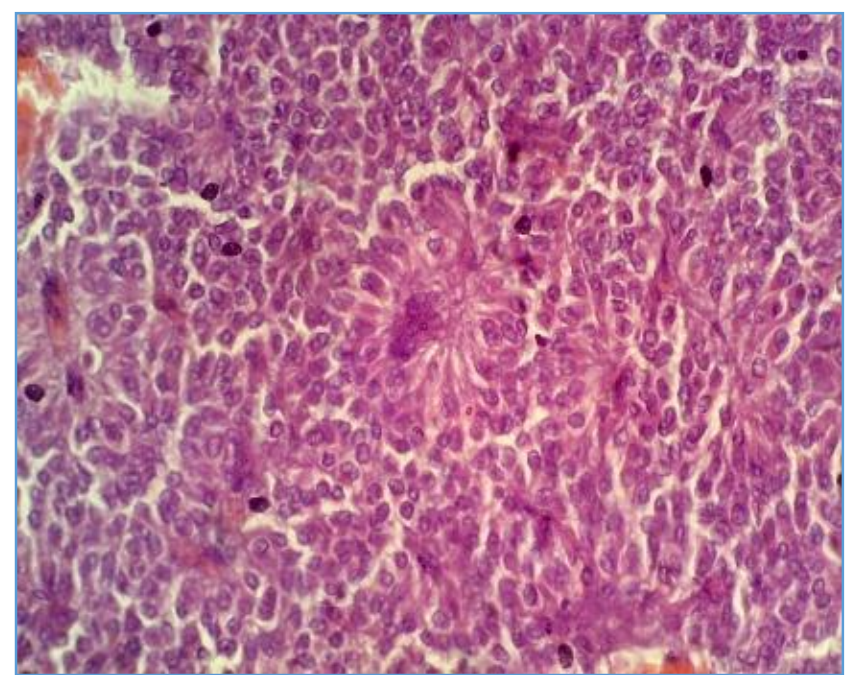

Figure 2. H and E (40X) Cells with Granular, Eosinophilic Cytoplasm and Round to Oval, Mildly Pleomorphic Nuclei. Mitotic Figures and Pseudorosettes Seen

Pathological examination is the mainstay in the diagnosis. Grossly, SPT is a well-encapsulated tumour. Cut section shows a variegated tumour with haemorrhagic and necrotic areas admixed with solid areas [Fig. 1]. Microscopically, the solid areas are composed of small and medium sized tumour cells. Tumour is very cellular and shows the presence of pseudopapilla covered by layers of epithelial cells. Nuclei is ovoid and folded with indistinct nucleoli and few mitosis [Fig.2]. It is worth noting that cystic changes are not a ubiquitous feature and instead usually occur in larger lesions secondary to long-standing tumour necrosis. The papillary appearance of the tumour is due to the cellular clustering around the microvasculature with more dyscohesive cells in the periphery and is not due to the presence of true papillary stalks. Immunohistochemical studies have shown that SPT is reactive for alpha- 1 antitrypsin, beta catenin, CD 56 [Fig. 3], CD 10, vimentin [Fig. 4], progesterone receptor, S100 protein, 
cytokeratin, desmoplakin, trypsin, chymotrypsin and amylase [Table 2].

Focal positivity has been observed with NSE and islet cell hormones, such as insulin and glucagon. This points that SPT arises from primitive pancreatic cells having dual differentiation, but with a predominance of exocrine features.[8,9] Presence of progesterone receptors with its predilection for females suggests that SPT is a hormone dependent tumour.[10,11] Histogenesis of SPT is unknown Ultrastructurally evidence of acinar, ductal and endocrine cell differentiation has been found.

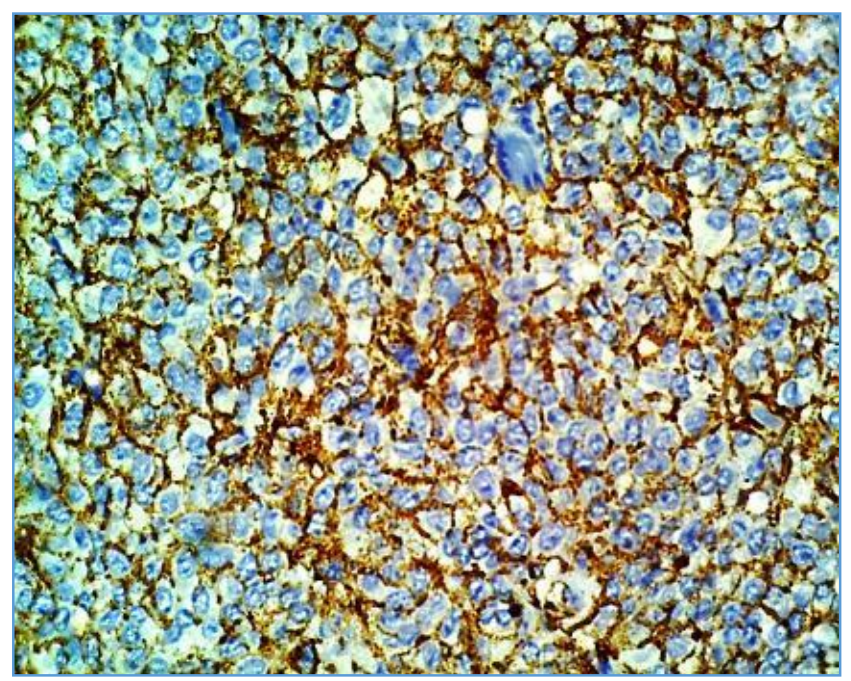

Figure 3. CD 56 Positive

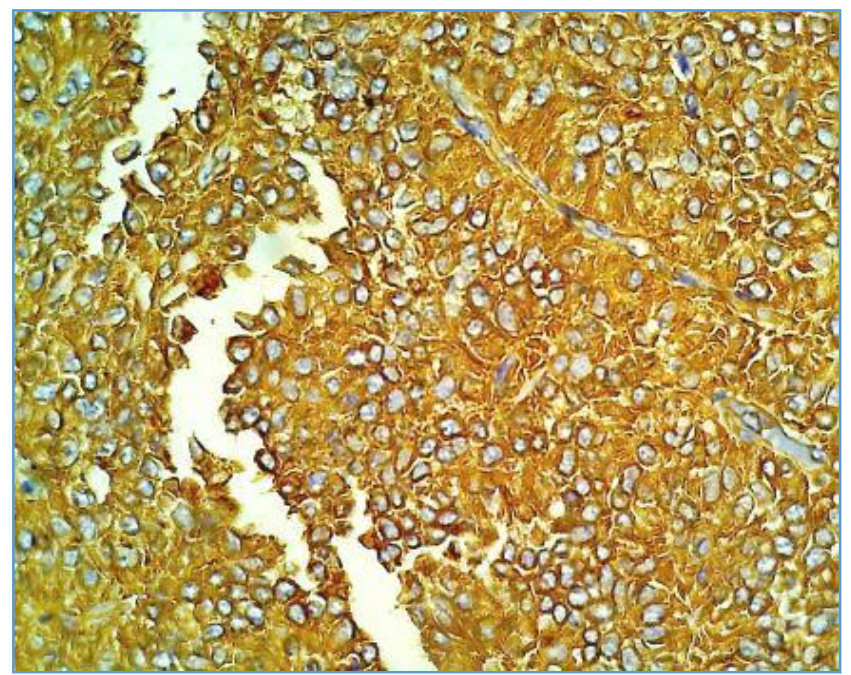

Figure 4. Vimentin Positive

Treatment of choice is complete surgical resection. A study from Memorial Sloan-Kettering Cancer Center, New York, USA, recommends complete surgical excision with even metastatectomy if required.[12] In our study, none of the cases had metastasis. A local recurrence rate of $6.2 \%$ is reported in cases treated by radical surgical excision.[13] In our series, all the patients are disease free on follow-up with no evidence of recurrence. SPT has an excellent prognosis with a low malignant potential. Aggressiveness is associated with cellular atypia, mitotic activity and lymphovascular, perineural or invasion of neighbouring organs. Metastasis is seen in regional lymph nodes, liver and omentum. On analysing our study, the results are in close proximity to the earlier studies conducted by Patil TB et al[14] and Ozguven BY et al[15] [Table 3].

\begin{tabular}{|c|c|c|c|}
\hline Criteria & Patil et al & Ozguven et al & Present Study \\
\hline Cases & 14 & 09 & 03 \\
\hline $\begin{array}{c}\text { Duration of } \\
\text { study }\end{array}$ & 10 years & 15 years & 02 years \\
\hline Sex & $\begin{array}{c}\text { All } \\
\text { females }\end{array}$ & $\begin{array}{c}8 \text { females, } \\
1 \text { male }\end{array}$ & $\begin{array}{c}\text { All } \\
\text { females }\end{array}$ \\
\hline Age (yrs.) & $\begin{array}{c}13-45 \\
\text { (median } 20)\end{array}$ & $\begin{array}{c}14-73 \\
\text { (median 32) }\end{array}$ & $\begin{array}{c}14-20 \\
\text { (median15) }\end{array}$ \\
\hline Site & $\begin{array}{c}\text { Equivocal } \\
(1: 1)\end{array}$ & $\begin{array}{c}\text { Tail } \\
(7: 2)\end{array}$ & $\begin{array}{c}\text { Head } \\
(2: 1)\end{array}$ \\
\hline Size (cm) & $\begin{array}{c}3-18 \\
\text { (average 6.8) }\end{array}$ & $\begin{array}{c}4-9 \\
\text { (average 5.8) }\end{array}$ & $\begin{array}{c}6-10 \\
\text { (average 7.3) }\end{array}$ \\
\hline $\begin{array}{c}\text { Post-operative } \\
\text { morbidity }\end{array}$ & 01 case & Nil & Nil \\
\hline $\begin{array}{c}\text { Post-operative } \\
\text { mortality }\end{array}$ & Nil & Nil & Nil \\
\hline $\begin{array}{c}\text { Table 3. Comparison between the Parameters in the } \\
\text { Present Study with those Reported in Two Previous Studies }\end{array}$
\end{tabular}

\section{CONCLUSION}

Solid pseudopapillary tumours have a low malignant potential and their prognosis is extremely good unlike other pancreatic tumours. A high degree of clinical suspicion is necessary to suspect and diagnose SPT. The widespread use of imaging techniques together with a better knowledge of the disease has prompted a rapidly increasing number of case reports. Surgical excision offers the best chance for cure and should always be attempted irrespective of the magnitude of the resection involved. Immunohistochemical and ultrastructural studies indicate that it must be regarded as a tumour of uncertain histogenesis and undetermined differentiation

\section{REFERENCES}

[1] Burdan F, Mocarska A, Guz E, et al. Solidpseudopapillary neoplasm of the pancreascomparisons between magnetic resonance and histological findings. Pol J Pathol 2013;64(3):216-23.

[2] Jeng LB, Chen MF, Tang RP. Solid and papillary neoplasm of the pancreas. Emphasis on surgical treatment. Arch Surg 1993;128(4):433-6.

[3] Matsunou H, Konishi F. Papillary - cystic neoplasm of the pancreas. A clinicopathologic study concerning the tumor aging and malignancy of nine cases. Cancer 1990;65(2):283-91.

[4] Papavramidis T, Papavramidis S. Solid pseudopapillary tumors of pancreas: review of 718 patients reported in English literature. J Am Coll Surg 2005;200(6):965-72.

[5] Frantz VK. Tumors of the pancreas. Atlas of tumor pathology 7. In: Fascicles 27 \& 28. Washington, DC: Armed Forces Institute of Pathology1959:32-3.

[6] Zhou H, Cheng W, Lang KY, et al. Solid-cystic papillary tumor of pancreas in children. Pediatr Surg Int 2001;17(8):614-20.

[7] Reddy S, Cameron JL, Scudiere J, et al. Surgical management of solid-pseudopapillary neoplasms of the pancreas (Franz or Hamoudi tumors): large single institutional series. J Am Coll Surg 2009;208(5):950-7. 
[8] Miettinen M, Partanen S, Fraki O, et al. Papillary cystic tumor of the pancreas. An analysis of cellular differentiation by electron microscopy and immunohistochemistry. Am J Surg Pathol 1987;11(11):885-65.

[9] Pettinato G, Manivel JC, Ravetto C, et al. Papillary cystic tumor of the pancreas. A clinicopathologic study of 20 cases with cytologic, immunohistochemical, ultrastructural and flow cytometric observations and a review of the literature. Am J Clin Pathol 1992;98(5):478-88.

[10] Nishihara K, Tsuneyoshi M, Ohshima A, et al. Papillary cystic tumor of the pancreas. Is it a hormone dependent neoplasm? Pathol Res Pract 1993;189(5):521-6.

[11] Zamboni G, Bonetti F, Scarpa A, et al. Expression of progesterone receptors in solid-cystic tumor of pancreas. A clinicopathological and immunohistochemical study of ten cases. Virchows Arch A Pathol Anat Histopathol 1993;423(6):425-31.
[12] Martin RC, Klimstra DS, Brennan MF, et al. Solid pseudopapillary tumor of the pancreas: a surgical enigma? Ann Surg Oncol 2002;9(1):35-40.

[13] Gonzalez-Campora R, Martin RJJ, Rodriguez VJL, et al. Papillary cystic neoplasm of the pancreas with liver metastasis coexisting with thyroid papillary carcinoma. Arch Pathol Lab Med 1995;119(3):268-73.

[14] Patil TB, Shrikhande SV, Kanhere HA, et al. Solid pseudopapillary neoplasm of the pancreas: a single institution experience of 14 cases. HPB (Oxford) 2006;8(2):148-50.

[15] Ozguven BY, Tuncel D, Polat N, et al. Solid pseudopapillary neoplasm of the pancreas: clinicopathologic and immunohistochemical analysis of nine cases. Indian J Pathol Microbiol 2015;58(3):292-5. 